\title{
Miba Śmac
}

\section{»Bratje Čehi« v ljubljanskem bogoslovju (1885-1897) "Czech Brothers" at the Ljubljana Seminary (1885-1897)}

Povzetek: V letih od 1885 do 1897 so v ljubljansko bogoslovje prihajali duhovniški kandidati s Češke in Moravske. Na Kranjskem je namreč duhovnikov primanjkovalo, na Češkem in Moravskem pa je v tem obdobju zanimanje za duhovne poklice cvetelo. Temu primerno so bila češka in moravska bogoslovna semenišča zapolnjena in mladi kandidati so si morali iskati mesta po drugih semeniščih v monarhiji. Tržaško-koprski škof Ivan Glavina (škof v letih 1882-1895) je tako dal pobudo ter povabil češke in moravske kandidate v Centralno goriško semenišče; odziv je bil velik in mnogi so pozneje uspešno delovali kot dušni pastirji v njegovi škofiji. Prošnje mladih čeških kandidatov pa so se znašle tudi v Ljubljani. Prispevek želi na podlagi arhivskega gradiva, časopisnih notic, pa tudi spominov na kratko orisati in osvetliti omenjeno obdobje prisotnosti »bratov Čehov«, ki so bili pozneje vpeti v življenje in skrb za dušni blagor ljudi, v ljubljanskem bogoslovju.

Ključne besede: Čehi, ljubljansko bogoslovje, duhovniški kandidati, študij, duhovniki, pastorala

Abstract: From 1885 to 1897, priesthood candidates from the Czech lands and Moravia enrolled at the Ljubljana seminary. There was a shortage of priests in Carniola, while in the Bohemia and Moravia the interest in the spiritual care was gradually increasing during that period. The Czech and Moravian seminaries were full, and the young candidates had to study at other seminaries in the Monarchy. The Bishop of the Diocese of Trieste-Koper (Capodistria) Ivan Glavina (1882-1895) presented the initiative and invited Czech and Moravian priesthood candidates to enrol at the central seminary in Gorizia. The response was overwhelming and many candidates to the priesthood successfully continued to work as priests in the diocese. The applications of young Czech and Moravian priesthood candidates were also sent to the Ljubljana seminary. On the basis of archival records and materials, newspaper notes and memoirs, the following paper briefly outlines and highlights the aforementioned period of the presence of the Czech and Moravian students at the Ljubljana seminary, who were later involved in the life and concern for the spiritual well-being of people.

Keywords: Czechs, Moravians, Ljubljana seminary, priesthood candidates, theological studies, priests, pastoral care 


\section{Uvodna beseda}

Vezi med deželami sv. Vaclava in deželami Notranje Avstrije so bile in so še predmet različnih raziskav - še posebej, ko je v ospredju vprašanje kulturnih povezav med češkimi in moravskimi deželami ter Kranjsko. Jonatan Vinkler (2006) je v svoji študiji Posnemovalci, zavezniki in tekmeci te kulturne stike, umeščene v 1. polovico 19. stoletja, prikazal, Borut Klabjan pa se je v monografiji Češkoslovaška na Jadranu poglobljeno lotil povezovanja med Čehi in Trstom (Klabjan 2007). Avtor je v navedenem delu izpostavil tudi vezi, ki so jih vzpostavljali duhovniki in pripadniki redovnih skupnosti. Pravzaprav bi prav slednje lahko uvrstili med prve, ki so davno pred univerzitetnimi študenti v kranjski svet prinašali poglede iz dežel sv. Vaclava. Posamezniki so sodelovali tudi pri nastajanju nekaterih najdragocenejših rokopisov - če pomislimo npr. na stiške rokopise, kjer je svoj pečat pustil tudi češki menih Martin, ki je v prvi polovici 15. stoletja vanje zapisal »molitev pred pridigo antifono Salve Regina « (Ambrožič 2010, 226). Prav iz čeških dežel, natančneje iz Olomouca, je bil k jezuitom v Ljubljano za prvega rektorja poslan pater Henrik Vivarij; tudi njegov naslednik je prišel iz češke skupnosti. Navsezadnje je bil prav prihod pregnanih članov jezuitske skupnosti z Moravske tisti, ki so leto 1619 naredili za enega od mejnikov pri razvoju visokošolskega študija v Ljubljani. V Letopisu ljubljanskega kolegija Družbe Jezusove za to leto namreč beremo:

» $\mathrm{V}$ juniju je zaradi izgona naših iz Moravske prišlo 15 novincev iz Brna s svojim magistrom p. Tomažem Lutringom in od starejših p. Martin Critaeus ter krojača Nikolaj Rudolphi in Janes Seel. /.../ Ko so bili pozneje novinci v novembru odposlani deloma v Italijo, deloma v Nemčijo, je na njihovo mesto prišlo osem starejših bratov, da bi tukaj študirali moralno teologijo pri profesorju p. Juriju Sturmu.« (Baraga 2003, 82)

Zdi se, da takšni stiki med duhovniki in redovniki, ki so na Kranjsko prihajali z Moravske in Češke, niso nikoli popolnoma zamrli. Najbrž zato ne preseneča ugotovitev, da se omembe posameznikov najde tudi v Pokornovem prvem letopisu. $\checkmark$ njem je denimo omenil duhovnika Jožefa Heltzla, profesorja I. gimnazijskega razreda: »Bil je Čeh iz litomerske škofije, v mašnika posvečen v Ljubljani na veliko soboto dne 30. marca 1771 na titel javorniškega gospostva barona Zoisa« (Pokorn $1908,11)$. Pokorn je med profesorji omenil tudi nekdanjega cistercijanskega patra Viljema: „Doma je bil na Češkem: ıSchwokensisı ter bil v mašnika posvečen dne 5. septembra leta 1773. « (11) Ti stiki torej niso bili redki in kot se zdi, so se posebej poglabljali zlasti v drugi polovici 19. stoletja.

Razlog za to je bilo tako zelo povečano zanimanje za duhovniški poklic med češkimi in moravskimi fanti, da so bila češka semenišča prenapolnjena in so preostali kandidati morali svoje mesto $v$ bogoslovju iskati po drugih škofijah, tako tudi v deželah Notranje Avstrije.

Prispevek želi na podlagi časopisnih notic, spominskih zapisov in do sedaj pregledanega arhivskega gradiva vsaj nekoliko osvetliti obdobje, ko so se v Ljubljani izobraževali tudi duhovniški kandidati s Češke in Moravske. 


\section{2. Čehi v beli Ljubljani}

»Bratje Čehi v beli Ljubljani« se je glasil naslov v Slovencu (11. 8. 1887), ko so poročali o slovesnem banketu v ljubljanski čitalnici ob njihovem obisku. Banket je bil prežet z različnimi slavilnimi govori, v katerih ni manjkalo besed o sodelovanju dveh narodov ter poudarjanju skupnih verskih, kulturnih in ustvarjalnih vezi. Pri tem so se sklicevali tako na iste težave, ki jih tarejo, želje, ki jih imata oba naroda v habsburškem imperiju, kot seveda tudi na kulturne in zgodovinske vezi, ki so se stkale med njima. Že dan prej je isti časopis poročal o prihodu Čehov v Ljubljano ter ob tem posebej izpostavljal tudi vezi, ki so se med Slovenci in Čehi tkale skozi stoletja zgodovine. Med drugim so tako zapisali, »da je v XIII. veku po Koroškem gospodstvu v naši deželi postal češki kralj Otokar vladar naše dežele ter si postavil Čeha Ulrika Dürnholza za deželnega glavarja, ki je stanoval v naši beli Ljubljani, in sicer na nekdaj sijajnem gradu Ljubljanskem. « Od tega časa, kakor stoji v časopisu, ni ostalo nobenega vpliva »in zgodovinske znamenitosti za nas Slovence« (S, 9. 8. 1887).

Sámo mesto je ob tem obisku bratov z Vltave doživljalo pravo prebujenje; tega pa so ob srečanju s svojimi rojaki zanesljivo doživljali vsi tisti Čehi, ki jih je službena (med temi npr. zlasti vojaki, uradniki, učitelji) ali življenjska pot pripeljala v glavno mesto dežele Kranjske. Kolikšno je bilo število Čehov in Moravanov, ki so dejansko živeli v Ljubljani? Vsaj okvirni odgovor na to vprašanje ponujajo podatki o popisu prebivalstva za leto 1880 in o občevalnem jeziku. Vlado Valenčič je na podlagi teh podatkov v pregledni tabeli navedel, da je bilo prebivalstvo po občevalnem jeziku, »ki je bil upoštevan le za avstrijske državljane», razdeljeno na 7 jezikovnih skupin; med temi je bil češki jezik zastopan s 87 posamezniki (brez vojaštva); skupaj s predstavniki vojske pa je mesto štelo 26.284 prebivalcev - od tega je kot občevalni jezik 136 oseb navedlo češkega (Valenčič 1974, 295). Ti podatki so le približni; zanesljivo pa je, da bi se v letu obiska ta številka lahko povečala vsaj še za nekaj oseb, ki so takrat prebivale v ljubljanskem semenišču.

\section{Semeniščniki $z$ Moravske in Češke $\mathbf{v}$ Ljubljani}

"Na Češkem in Moravskem je bilo v tistih časih vsako leto toliko abiturientov, da so si nekateri morali iskati kruha izven svoje domovine. Ker je pri nas manjkalo duhovnikov, jih je Missia rad jemal v bogoslovje« (Mlakar 1940, 226), je v spominih zapisal duhovnik in pisatelj Janko Mlakar (1874-1953). Ignacij Nadrah (18681951) pa je bil v memoarih še nekoliko podrobnejši: „L. 1888 in naslednja leta je bilo sprejetih nekaj Čehov v ljubljansko semenišče (Vondràšek, Filler, Železny in dr[ugi]), med njimi tudi Čekal« (Ambrožič 2010a, 71).

Borut Klabjan je v monografiji Češkoslovaška na Jadranu posebej omenil prisotnost večjega števila čeških duhovnikov v tržaško-koprski škofiji, in sicer že v času škofa Jerneja Legata (1846-1875), ko je tam delovalo 26 duhovnikov »po rodu s Češke, 12 pa jih je bilo v poreško-puljski škofiji« (Klabjan 2007, 193). Še več jih je prišlo, ko se je na Čehe obrnil škof Ivan Glavina, tržaško-koprski škof v letih 1882- 
1895. V času bolezni je škof Glavina leta 1885 obiskal toplice v Karlovih Varih, kjer je navezal stike s češkimi škofi. V naslednjem letu je $v$ časopisnih vrsticah javnost obvestil o pomanjkanju duhovnikov v Istri. Odziv na to je prišel v obliki večjega števila prošenj za vstop v Centralno goriško semenišče, kamor je potem dejansko prišlo večje število duhovniških kandidatov (193). So torej (šele) po tem pozivu začeli češki in moravski kandidati prihajati tudi v Ljubljano ali pa so na vrata ljubljanskega semenišča trkali tudi že prej?

Prvi odgovor na omenjeno vprašanje je bilo mogoče pridobiti s pregledom vsakoletnih letopisov ljubljanske škofije, ki predstavljajo »svojevrsten vir za zgodovino ljubljanske (nad)škofije», kakor jih je označil France M. Dolinar (1982, 231). Pri tem je bilo smiselno pregledati še letopise za leta pred že omenjenim obdobjem iz Nadrahovih spominov, pa tudi tiste, ki so izšli v letih pred natisnjenim vabilom škofa Glavine.

Leta 1880 je letopis ljubljanske škofije izšel v latinskem jeziku. Med študenti bogoslovci - teh je bilo takrat 37 - ni bilo iz čeških dežel nikogar (Catalogus cleri 1880, 93-94). V naslednjem letu je bilo študentov 41, a tudi med njimi iz čeških dežel zopet nikogar (1881, 93-94). Enako velja za leto 1882. Takrat je bil v prvem letniku kot tuj študent vpisan le Sebastian Elbert, rojen 23. januarja 1860 v Deidesheimu na Bavarskem. Kot »tujega « pa je mogoče šteti tudi Mihaela Bulovca, ki je bil sicer Tržačan (1882, 93-94). V letopisu iz leta 1883 je vpisanih 54 študentov, med njimi v prvem letniku iz čeških dežel še vedno ni nikogar (1883, 93-95). Enako število bogoslovcev je mogoče najti tudi v šematizmu za leto 1884, a čeških predstavnikov še vedno ni (1884, 93-94). V letopisu za leto 1885 je navedenih 51 bogoslovcev zopet brez čeških predstavnikov (1885, 93-95). Do spremembe pride šele v letopisu za leto 1886, kjer so navedli, da je v semenišču 67 kandidatov. V prvem letniku je med 27 študenti mogoče najti tudi češke duhovniške kandidate (1886, 93-95).

$Z$ gotovostjo je torej mogoče reči, da so prvi kandidati iz dežel sv. Vaclava prihajali v Ljubljano že v letu 1885, torej še pred vabilom škofa Glavine. Razlog za to je bil preprost in o tem je poročal tudi Slovenec (29. 8. 1885):

»(V bogoslovje) oglaša se pri nas od leta do leta manj osmošolcev. Letos prosilo je za sprejem trinajst kandidatov, od kterih jih le pet Ljubljanski veliki gimnaziji pripada. Več veselja do duhovskega stanu imajo mladenči na Češkem, kjer jih je za sprejem v Budejoviško semenišče več nego sto prosilo. Ker nimajo za tolikanj kandidatov niti prostora niti sredstev, jih mnogo niso sprejeli. Nekteri tistih so se obrnili do našega knezoškofa za sprejem v Ljubljansko bogoslovje."

\section{Prve prošnje}

Dejansko so prošnje takrat res vložili predvsem kandidati iz škofije České Budějovice (nem. Budweis); tudi iz škofije Hradec Králové (nem. Königgrätz) sta bila dva prosilca, eden pa je prihajal iz brnske (Brünn) škofije (NŠAL, ŠAL V. Semenišče 
1881-1890, šk. 229, An das Hochwürdigste Fürstbischöfliche Ordinariat, 9. 9. 1885). Ob prvih prošnjah za vstop v bogoslovje so kandidati prilagali potrebne dokumente in dokazila, tudi Litterae testimoniae domačih škofov za posameznika; pri priloženi dokumentaciji je bilo vodstvo posebej pozorno na ocene v spričevalu, in sicer zlasti iz filozofije in verouka. Semeniško vodstvo je v poročilu škofijskemu ordinariatu septembra tistega leta poročalo o vsakem kandidatu posebej. Med prvimi, ki so prosili za vstop v ljubljansko bogoslovje, je bil Frančišek Hiersche (Počátky, škofija Budweis), ki je maturiral v Neuhausu. Bil je moralno vzoren, pa tudi ocene iz verouka in filozofije so bile vzorne; tudi sicer je imel zelo dobre ocene in bil iz upoštevanja vredne družine. Prošnjo na ljubljansko semenišče je naslovil tudi Alojz Svoboda, doma iz škofije Königgratz. Obiskoval je češko gimnazijo; pri filozofiji je bil ocenjen »povoljno«. Svoboda je že prej poskusil vstopiti v dve semenišči, vendar ni uspel (NŠAL, ŠAL V., Semenišče 1881-1890, šk. 229, An das Hochwürdigste Fürstbischöfliche Ordinariat, 9. 9. 1885). Poleg omenjenih dveh so tistega leta prošnje vložili še nekateri drugi; med njimi kandidati Marek (škofija Budweis), Mensinger (škofija Königgratz), Partl (Budweis), Kunstovný (Budweis), Lakmaier [sic!] (Budweis) in Bilik (škofija Brünn). Kot lahko razberemo iz poročila, vsem prosilcem niso mogli ugoditi, nekateri pa kljub sprejemu nato niso želeli vstopiti sami. Očitno so si, kakor je zapisano, premislili in izbrali drugo življenjsko pot: "Alois Svoboda und Josef Mantura haben dagegen ihren Entlassung sich dem geistlichen Stande zu widmen, aufgegeben « (NŠAL, ŠAL V., Semenišče 1881-1890, šk. 229, An die hochw. Direktion des fb. Klerikalseminar in Laibach, 3. 10. 1885). Svoboda in Mantura sta si torej drugačno življenjsko pot izbrala sama, druga dva kandidata za vstop, Kunstovnega in Pártla, pa je zavrnilo vodstvo semenišča (NŠAL, ŠAL V., Semenišče 1881-1890, šk. 229, Höchwürdigtes fürstbischöfliches Ordinariat, Laibach am 25. Sept. 1885). Tudi še v naslednjih akademskih letih so marsikaterega prosilca iz različnih razlogov zavrnili ali pa si je premislil sam.

\section{Sprejeti bogoslovci v luči šematizmov}

O tistih, ki so bili v ljubljansko semenišče sprejeti, je večkrat poročalo slovensko časopisje. Že 9. oktobra 1885 je Slovenski narod med drugim objavil naslednjo vest: »(V Ljubljansko semenišče) v prvo leto ustopilo je letos 27 bogoslovcev, mej njimi 6 Čehov. Na Češkem so semenišča prenapolnjena in abiturijenti iščejo po drugih kronovinah prostora. Tako so tudi v Gradci več Čehov v bogoslovje vsprejeli« (SN, 9. 10. 1885). Zanimivo je, da časopisje v tem primeru navaja šest čeških kandidatov; v letopisu škofije jih najdemo omenjenih le 5: Vojteh (Adalbert) Havliček, Frančišek Hiersche, Franc Lakmaier, Jožef Mensinger, Alojzij Železný (Catalogus cleri 1886, 95). Prvi prihod čeških bogoslovcev v deželno glavno mesto ob Ljubljanici pa, kot se zdi, ni bil povsod sprejet z navdušenjem. Iz časopisne notice lahko razberemo, da so v letu 1886 »nergaški glasovi« v enem od tedenskih listov glasno nastopili proti Čehom v ljubljanskem bogoslovju. Komentator tega dogajanja je v prispevku v Slovencu navedel, da je veliko število čeških abiturientov pro- 
silo za sprejem v druga semenišča: „V Gorico jih je doslej 25 prosilo, v nemški Gradec jih prosi šestdeset, tako primeroma tudi v Maribor, $v$ Celovec in na Dunaj več, kakor jih sprejeti morejo. - Kaj bo po tem takem pa neki prestrašen tedenski listič rekel, ki že čez to nergá, da Ljubljansko semenišče v spolnitev potrebnega števila kakih pet ali šest kandidatov iz Českega [sic!] sprejmé, zlasti še kterega, ki je maturo izvršil z odliko? Pa naj reče, kar mu drago « (S, 20. 8. 1886). Posamezni nezadovoljni glasovi sicer na nove prihode čeških kandidatov niso vplivali, saj so se ti s prošnjami za vstop v ljubljansko bogoslovje oglašali še naprej. V akademskem letu 1886/1887 je v glavnem mestu dežele Kranjske študiralo 77 bogoslovcev. $\checkmark$ prvem letniku je bilo takrat 25 duhovniških kandidatov, od tega kar osem Čehov iz škofije Budweis (Catalogus cleri 1887, 99-101). Že v naslednjem letu je bilo v semenišču kar 80 bogoslovcev, ob tem pa je bilo še 9 študentov, ki so študirali drugod: Janez Koren in Frančišek Ušeničnik sta denimo takrat študirala v Rimu. Prvi letnik ljubljanskega bogoslovja je tudi takrat obiskovalo 25 študentov, med temi pa je bil tokrat iz dežele sv. Vaclava le en kandidat: Vencelj Filler $(1888,114-$ 118). $V$ akademskem letu $1888 / 1889$ je bilo število bogoslovcev enako kot leto prej; od tega pa tokrat v prvem letniku le 10 študentov in med njimi nobenega Čeha. Je pa zato v tem letu posebej izpostavljena notica o bogoslovcu Havličku, saj je bil takrat valetudinarij $(1889,130-136)$. Tudi v prihodnjih dveh akademskih letih $(1889 / 1890$ in 1890/1891) Čehov v prvem letniku ni bilo. Njihovi predstavniki se znova pojavijo $v$ akademskem letu $1891 / 1892$. Tega leta je prvič prestopilo prag ljubljanskega bogoslovja 17 kandidatov, med njimi tudi Franc Saleški Finžgar. V njegovem letniku sta se po letih »suše« znašla tudi dva kandidata iz čeških dežel: Viljem (Guilielumus) Paulus, doma iz Neuhausa na Češkem, in Karel Boromejski Volenec, doma iz vasi Kluky $(1892,131-135)$. Tudi v naslednjem letu so se v ljubljanskem bogoslovju med 21 prvoletniki znašli trije Čehi, ki so bili sošolci poznejšega skopskega škofa in božjega služabnika Janeza Gnidovca (1873-1939) (1893, 150-154). Zadnji »val« čeških kandidatov predstavljajo štirje prosilci: Anton Dráb, Vojteh Hybašek, Alojzij Janovský in Frančišek Šima. Vsi ti so bili v ljubljansko bogoslovje sprejeti v akademskem letu 1893/1894. Takrat je bilo v prvem letniku 22 bogoslovcev, med katerimi sta bila tudi poznejši pisatelj Janko Mlakar in vidni politik Evgen Lampe (1874-1918) (1894, 151-155). Za njimi v ljubljanskem bogoslovju do konca 19. stoletja ni študiral noben kandidat s Češke ali Moravske več.

\section{Okvirna tabela vseh slušateljev s Češke in Moravske}

Letopisi ljubljanske škofije so pri sestavljanju seznama vseh študentov, ki so v ljubljanskem bogoslovju študirali vsaj kratek, prispevali le nekaj temeljnih informacij. Nekaj več podatkov, četudi ne vseh, pa razkrivajo katalogi slušateljev. Na podlagi pregledanega arhivskega gradiva, časopisja in letopisov je bilo mogoče sestaviti naslednjo okvirno tabelo. ${ }^{1}$

Za pomoč pri lociranju navedenih rojstnih krajev in navedbo današnjih imen se zahvaljujem zgodovinarju Klemenu Lužarju. 


\begin{tabular}{|c|c|c|c|c|c|}
\hline Ime in priimek & Rojstni datum & Rojstni kraj & $\begin{array}{c}\text { Škofija (v } \\
\text { nem. zapisu } \\
\text { imena) }\end{array}$ & Poklic očeta & $\begin{array}{l}\text { Ordini- } \\
\text { ran }\end{array}$ \\
\hline $\begin{array}{l}\text { Havliček } \\
\text { Adalbert }\end{array}$ & 15. 4. 1866 & $\begin{array}{c}\text { Weißhurka (češ. Hůrka } \\
\text { Bílá), Böhmen }\end{array}$ & Budweis & \begin{tabular}{|c|} 
zemljiški posestnik \\
(Grundbesitzer)
\end{tabular} & \\
\hline Hiersche Franciscus & 14. 12. 1866 & $\begin{array}{l}\text { Potschatek (češ. Poča- } \\
\text { tek/Počátky), Böhmen }\end{array}$ & Budweis & doktor prava & 1889 \\
\hline $\begin{array}{l}\text { Lakmayer (Lakmaier) } \\
\text { Franciscus }\end{array}$ & 24. 7. 1863 & $\begin{array}{l}\text { Hosin (češ. Hosín) } \\
\text { Böhmen } \\
\end{array}$ & Budweis & $\begin{array}{c}\text { učitelj (Schulle- } \\
\text { hrer) }\end{array}$ & 1888 \\
\hline Mensinger Joseph & 25. 7. 1864 & $\begin{array}{l}\text { Elbeteinitz (češ. Týnec } \\
\text { nad Labem), Böhmen }\end{array}$ & Königgrätz & meščan (Burger) & 1889 \\
\hline Železny Aloysius & 16. 4. 1867 & $\begin{array}{c}\text { Zdikau (češ. Zdíkov), } \\
\text { Böhmen } \\
\end{array}$ & Budweis & $\begin{array}{c}\text { posestnik mlina } \\
\text { (Mühlbesitzer) }\end{array}$ & 1889 \\
\hline Čekal Ferdinand & 26. 1. 1866 & $\begin{array}{l}\text { Wobratain (češ. Obra- } \\
\text { taň), Böhmen }\end{array}$ & Budweis & kmet & 1889 \\
\hline Dvǒrak Josephus & 28. 2. 1867 & $\begin{array}{c}\text { Klokot (češ. Klokoty), } \\
\text { Böhmen }\end{array}$ & Budweis & & \\
\hline Kosobud Eduard & 12. 3. 1867 & $\begin{array}{c}\text { Tabor (češ. Tábor), } \\
\text { Böhmen }\end{array}$ & Budweis & pekovski mojster & 1890 \\
\hline Martan Wencesl. & 27. 6. 1866 & $\begin{array}{l}\text { Wodnian (češ. } \\
\text { Vodňany), Böhmen }\end{array}$ & Budweis & \begin{tabular}{|l} 
upokojeni davkar \\
(Steuereinheimer) \\
\end{tabular} & \\
\hline Rehoř Joannes & 30. 3. 1862 & Pisek (češ. Písek), Böhmen & Budweis & & \\
\hline Soukup Joannes Nep. & 11. 5. 1867 & $\begin{array}{l}\text { Wondrichow (češ. } \\
\text { Ondřichov), Böhmen }\end{array}$ & Budweis & $\begin{array}{l}\text { manželsky-po- } \\
\text { ročen }\end{array}$ & 1890 \\
\hline Vondrášek Thomas & 19. 10. 1866 & $\begin{array}{c}\text { Protiwin (češ. Protivín), } \\
\text { Böhmen }\end{array}$ & Budweis & & \\
\hline Vondrášek Wencesl. & 13. 9. 1865 & $\begin{array}{l}\text { Burgholz (češ. Purka- } \\
\text { rec), Böhmen }\end{array}$ & Budweis & kmet (Rolnik) & 1890 \\
\hline Filler Wencesl. & 17. 7. 1866 & $\begin{array}{c}\text { Bechlin (češ. Bechlín), } \\
\text { Böhmen }\end{array}$ & Prag & \begin{tabular}{|c|} 
zemljiški posestnik \\
(Grundbesitzer)
\end{tabular} & 1891 \\
\hline Paulus Guilielmus & 20. 5. 1872 & $\begin{array}{l}\text { Neuhaus (češ. Jindři- } \\
\text { chův Hradec), Böhmen }\end{array}$ & Budweis & kmet & 1895 \\
\hline $\begin{array}{l}\text { Volenec Carolus } \\
\text { Borom. }\end{array}$ & 6. 5. 1871 & $\begin{array}{c}\text { Kluk (češ. Kluky), } \\
\text { Böhmen (?) }\end{array}$ & Königgrätz & kmet (Agricola) & \\
\hline Burjánek Adalbertus & 22. 4. 1869 & $\begin{array}{c}\text { Strenitz (češ. Strenice), } \\
\text { Böhmen }\end{array}$ & Leitmeritz & kmet (Agricola) & \\
\hline Fiála Carolus Mag. & 11. 1. 1871 & $\begin{array}{c}\text { Pribram (češ. Př́bram), } \\
\text { Böhmen }\end{array}$ & Prag & $\begin{array}{c}\text { mlinar (Molenda- } \\
\text { rius) }\end{array}$ & \\
\hline Hubálek Adolphus & 9. 10. 1871 & $\begin{array}{c}\text { Lukawice (češ. Lukavi- } \\
\text { ce), Böhmen }\end{array}$ & Königgrätz & kmet (Agricola) & \\
\hline Dráb Anton Pat. & 13. 6.1873 & $\begin{array}{c}\text { Datschitz (češ. Dačice), } \\
\text { Mähren }\end{array}$ & Brünn & kmet (Agricola) & \\
\hline Hybášek Adalbertus & 27. 3. 1871 & $\begin{array}{c}\text { Rosenau (češ. Růžená), } \\
\text { Mähren }\end{array}$ & Brünn & $\begin{array}{l}\text { učitelj (Ludi } \\
\text { magister) }\end{array}$ & 1897 \\
\hline Janovsky Aloysius & 7. 8.1871 & $\begin{array}{l}\text { Malschitz (češ. Malši- } \\
\text { ce), Böhmen }\end{array}$ & Budweis & kmet (Agricola) & \\
\hline Šima Franciscus & 24. 1. 1874 & $\begin{array}{l}\text { Radomilitz (češ. Rado- } \\
\text { milice), Böhmen }\end{array}$ & Budweis & kmet (Agricola) & \\
\hline
\end{tabular}

Tabela 2: Okvirni seznam študentov s Češke in Moravske v ljubljanskem bogoslovju v letih 1885-1897 (NŠAL 32, Bogoslovno semenišče v Ljubljani, šk. 75, Katalogi slušateljev teologije 1885-1897). 
Iz tabele je mogoče razbrati, da je bil med Čehi in Moravani v ljubljanskem bogoslovju v največji meri zastopan letnik $1866 \mathrm{~s}$ šestimi predstavniki; sledijo jim fantje letnika 1871 (5) in tisti, ki so bili letnik 1867 (4). Vsi ostali so prispevali po enega kandidata (z izjemo letnika 1868, ki svojega predstavnika ni imel). Najstarejši kandidat Janez Rehoř je bil letnik 1862, najmlajši pa Franc Šima, ki je bil rojen v prvem mesecu leta 1874.

\section{Socialno poreklo}

Omenjeni letniki rojstev nekako kar sami postavljajo tudi vprašanje, iz kakšnih družin so ti kandidati izhajali. Katalogi slušateljev podajajo le nepopoln odgovor, saj jih niso vedno izpolnjevali v celoti - tako so $v$ formularju rubriki o imenu in poklicu očeta marsikdaj kar izpustili. To predstavlja težavo predvsem pri tistih kandidatih, ki so morda že v naslednjem semestru ljubljansko bogoslovje zapustili in odšli drugam. Res je, da bi iskane podatke morda lahko odkrili v prošnjah, ki so jih kandidati naslavljali na semeniško vodstvo pred sprejemom, vendar tudi pri tem gradivu, kolikor ga je bilo mogoče $v$ danem času pregledati, vse prošnje niso popolne. Kljub temu pa zbrani podatki nekaj malega o socialnem poreklu čeških in moravskih bogoslovcev vendarle odstirajo. Matjaž Ambrožič je v razpravi o študentih podal vzorčno analizo za absolvente teologije v prvih treh desetletjih 19. stoletja: »Ni potrebno ugibati, da jih je bila velika večina, skoraj dve tretjini, kmečkega porekla, nato so sledili sinovi različnih obrtnikov, rudarjev (Idrija), meščanov in uradnikov. Izredno malo duhovnih poklicev so dale družine uradnikov, zdravnikov in veleposestnikov - plemstva« (Ambrožič 2010b, 411). Ob koncu istega stoletja je bilo, če sodimo le po podatkih za češke in moravske bogoslovce, stanje deloma precej podobno. Od naštetih 23 je osem kandidatov navedlo, da je njihov oče kmet (Agricola/Rolnik); dva sta pri očetu navedla, da je zemljiški posestnik, eden je bil pekovski mojster, eden je bil mlinar, eden posestnik mlina (Mühlbesitzer); eden meščan (Burger); dva sta bila učitelja, pri enem pa lahko preberemo le zakonski stan "poročen« (manželsky); eden je bil upokojeni davkar in le eden doktor prava (NŠAL 32, Bogoslovno semenišče v Ljubljani, šk. 75, Katalogi slušateljev teologije 1885-1897). Pri ostalih za zdaj podatkov žal nimamo oziroma ti v gradivu, pregledanem do sedaj, (še) niso bili najdeni. Iz zapisanega lahko razberemo, da je pretežni del kandidatov sicer izhajal iz kmečkih družin, da pa so duhovniški kandidati izhajali tudi iz premožnejših (predvsem uradniških) družin, torej iz srednjega sloja. Med obravnavanimi kandidati pa ni zaslediti nobenega iz plemiških vrst.

\section{Poizvedbe o čeških kandidatih}

Navedeni podatki o posameznem kandidatu postrežejo le z drobci informacij, semeniško vodstvo pa je, kakor kaže, o njih želelo vedeti precej več. $V$ ta namen so 
se obračali tako na škofe kot tudi na posamezne duhovnike na Češkem in od njih o posameznih kandidatih prejemali dodatne podatke. Takšna poizvedba je bila opravljena tudi pri Ferdinandu Čekalu. V odgovoru s Češke je bilo zapisano, da je Čekal »Ein sehr begabter Junge«, odličen dijak in moralnega duha, o katerem ne morejo povedati ničesar slabega (NŠAL, ŠAL V., Semenišče 1891-1899, šk. 230, Reverendissime). Podobno so se pozanimali tudi o nekaterih drugih, npr. o Vojtehu Hybašku in Antonu Drábu. Pri tem je zanimivo, da so se na gimnazijsko vodstvo gimnazije, ki sta jo oba obiskovala, obrnili v njuni domači škofiji. S škofijskega ordinariata so za Hybaška med drugim sporočili notico z gimnazije, kjer so izrecno izpostavili 16 ur zapora, s katerim je bil Hybašek kot osmošolec kaznovan zaradi enkratnega obiska gostišča v bližini šole. Sicer pa je bila ocena o njem »razveseljujoča (NŠAL, ŠAL V., Semenišče 1891-1899, šk. 230, № 7663). Tudi na podlagi takšnih notic je vodstvo torej vedelo, s kom ima opraviti in kaj lahko od kandidatov pričakuje pri samem študiju - pri katerem jim niti jezik ne bi smel predstavljati večje ovire.

\section{9. Študij in jezikovne ovire}

Takratni študijski program, ki je veljal v študijskih letih od 1857/58 do 1918/19, je vseboval naslednja predavanja: v prvem letniku osnovno bogoslovje, fundamentalno teologijo, filozofijo (Tomaž Akvinski), splošno biblično hermenevtiko, hebrejščino, uvod in eksegezo Stare zaveze ter biblično arheologijo (ukinjeno 1893) in poseben uvod v svete knjige Nove zaveze (poleg obveznih predmetov je bilo mogoče poslušati tudi izredne: sirsko, kaldejsko in arabsko slovnico); v drugem letniku dogmatiko, eksegezo evangelijev, eksegezo in uvod v Novo zavezo ter cerkvene umetnosti; $v$ tretjem letniku so študentom predavali profesorji moralne teologije, cerkvene zgodovine in cerkvene umetnosti; v četrtem letniku pa profesorji pastoralne teologije, cerkvenega prava, katehetike, pedagogike (Ambrožič 2010b, 439442).

Predavanja so bila v jeziku Cerkve - latinščini. Janko Mlakar je o tem v spominih zapisal:

„Učni jezik je bil splošno latinski. Čeprav smo se ga učili osem let, je trajalo precej časa, da smo se ga navadili. Seveda na gimnaziji smo samo prevajali, tu smo pa morali govoriti. Pri drugih profesorjih je še nekako šlo, ker niso gledali na slovnico, pri dr. Lampetu pa ne. Ta je namreč predaval v prav klasični latinščini. /.../ Dr. Lampe je tako hitro govoril, da smo ga prav malo razumeli. Povedali smo to ravnatelju, pa ni nič pomagalo. Profesor nam je v lepi slovenščini pojasnil, da mora latinski predavati, ker ta jezik vsi razumemo, Slovenci, Nemci in Čehi, ter se je trdovratno držal učnega jezika» (Mlakar 1940, 209-210).

Tudi Ignacij Nadrah se je v svojih zapisih pritoževal nad Lampetom in njegovim načinom poučevanja, češ da s takšnimi predavanji »ni mogel biti nihče prav zado- 
voljen«. A Nadrah je bil razmeroma neprizanesljiv do vseh profesorjev, ki so takrat poučevali: »Naši profesorji niso bili najboljši. Kako vse drugače bi bilo z našo bogoslovno izobrazbo, če bi bili vsi naši profesorji možje na svojem mestu. To je zelo velik greh cerkvenih predstojnikov, da ne poskrbe za dobre profesorje že - in radice« (Ambrožič 2010a, 133).

Nad tem so se gotovo lahko pritoževali tudi češki kandidati, ki pa so se v bogoslovju morali spopasti še z drugo obvezo: slovenskim jezikom. Tega so se morali priučiti v dveh letih, kot so od njih zahtevali že ob samem sprejemu (NŠAL, ŠAL V., Semenišče 1881-1890, šk. 229, Höchwürdigtes fürstbischöfliches Ordinariat, Laibach am 25. Sept. 1885). V veliki meri je večini od njih to zelo dobro uspelo. Janez Evangelist Krek, ki je bil v času, ko so v semenišče prihajali prvi češki kandidati, študent 2. letnika, je imel dovolj priložnosti spremljati njihov napredek vse do konca svojega študija. V pismu prijatelju iz februarja 1888 je nekaj besed zapisal tudi o čeških bogoslovcih: „Čehi tretjega leta so se že prav dobro naučili slovenski - Hiersche in Lakmayer sta nastopila pri govorniških vajah z jako dobrim uspehom« (Dolenec 1923, 62).

Zahteva o priučitvi slovenskega jezika je veljala za vse češke kandidate, tako tudi Mlakarjeve sošolce, ki jih je pri izvajanju te zahteve lahko od blizu opazoval. Nekaterim med njimi je slovenski jezik delal nekaj težav; posledično so marsikdaj čisto nehote - poskrbeli tudi za dobro mero smeha in veselja med bogoslovci. $V$ svojih spominih navaja več drobnih prigod; naj navedemo le tisto, ki jo je zakuhal nekoliko starejši Čeh Burjanek, zaveden in navdušen narodnjak. Zaradi tega so ga kolegi večkrat dražili in nalašč zabavljali nad Čehi: »)Kaj se boš ustil, ( mu jo je zabrusil pri neki taki priliki Oswald, 'saj se na vas vidi, kakšni ste Čehi!' 'Moraš to upoštevati, da pridejo k vam samo slabi, kar je pa dobrih, ostanejo doma.' Ves kapitelj se je tej »samohvali« glasno smejal« (Mlakar 1940, 226-227). O semeniščniku Janovskem pa je Mlakar zapisal, da je slovensko govoril slabo, »ker je bil Čeh «, da pa je jezik govoril v »najčistejši elščini« (185). Zdi pa se, da bi bilo pri tem treba upoštevati še nekaj - da fant preprosto ni imel dovolj časa, da bi se jezika zares naučil, saj je semenišče zapustil dokaj kmalu.

\section{Odhodi semeniščnikov}

Odhodi iz semenišča niso bili nobena posebnost, razlogi pa so bili seveda različni: od bolezni, ljubezni pa vse do tega, da so si kandidati med študijem premislili in izbrali drugo pot ali pa ugotovili, da je študij teologije za njih morda pretežak. Janko Mlakar je zapisal, da je med mladimi ljubljanskimi akademiki obstajalo prepričanje, da s študijem teologije lahko opravi vsak - toda še zdaleč ni bilo tako! Teološki študij je bil dovolj zahteven, $v$ hiši pa je med bogoslovci veljalo tudi pravilo, da je moral vsak »v določenem času 'zdelati' ', v nasprotnem primeru se je moral od teologije posloviti, pa če je to želel ali ne: "Le komur niso hoteli preprečiti vstopa v kako drugo semenišče, so mu dali iz usmiljenja 'sufix'« (Mlakar 1940, 209). 
Tudi med češkimi kandidati nekaterim ni šlo in so zaradi neopravljenih izpitov morali ljubljansko bogoslovje zapustiti. Med takšnimi je bil tudi Jan Rehoř, o katerem je semeniško vodstvo obvestilo škofijski ordinariat in zapisalo, da kot alumen 1. letnika v drugem semestru v dveh poskusih izpita ni opravil, zaradi česar je potem ljubljansko bogoslovje zapustil (NŠAL, ŠAL V., Semenišče 1881-1890, šk. 229, Z. 204, Laibach 1. August 1887). Nekateri so odšli tudi zaradi bolezni in se pozneje niso več vrnili. Tak je bil primer Venclja Martana, študenta 3. letnika, ki se je ob koncu akademskega leta 1889 zaradi bolezni vrnil domov (NŠAL, ŠAL V., Semenišče 1881-1890, šk. 229, Z. 166, Laibach am 21. August 1889).

O nekoliko drugačnih razlogih za odhod svojega sošolca Drába pa je pisal Janko Mlakar v svojih spominih. Dráb je moral oditi, »ker je bil len in omejen. Najljubše njegovo delo je bilo, da je lepil škatlice in si delal umetne kodre. Prvi semester je še nekako zlezel, na koncu leta mu je pa ravnatelj dobrohotno, pa odločno svetoval, naj si izbere kak drug stan, ki se bolj sklada s fabriciranjem kodrov kakor teologija. Dejal sem, da je bil omejen; pa je bil res. Nekoč ga je dr. Lampe vprašal fundamentalko. Ker ni niti ust odprl, mu je profesor v najčistejši latinščini dejal, naj rajši izstopi, če nima ne veselja ne poklica za duhovski stan. Fant je pa mislil, da mu hoče pomagati na postavljeno vprašanje, zato mu je ves čas pritrjeval, pridno kimal in gonil svoj 'ita, ita'.. Mi smo z največjo težavo zadrževali smeh. Naposled ga je Oblak, ki je sedel za njim, dregnil v hrbet in kar na glas rekel: »Tepec, ali ne razumeš, da te zmerja?« (Mlakar 1940, 209)

Pri Mlakarjevih besedah je morda vendarle na mestu nekaj zadržanosti. Na to opozarja tudi dejstvo, da je Dráb iz ljubljanskega semenišča sicer zares odšel, v dokumentih pa se najde zapis, da je bil potem sprejet v semenišče v Brnu (NŠAL, ŠAL V., Semenišče 1891-1899, šk. 230, Laibach am 9. August 1895). Almanach des katholischen Klerus Oesterreichs und Ungarns iz leta 1912 (146) celo navaja nekega duhovnika Antona Drába, ki je deloval v vikariatu Moldautein v škofiji Budweis. Za zdaj pa (še) ni mogoče z gotovostjo potrditi, ali gre prav za Mlakarjevega sošolca. Če se izkaže, da je tako, bi to Mlakarjev spominski zapis postavilo v precej drugačno luč.

Dráb seveda ni bil edini iz generacije, ki je odšel, saj so se bili nekateri prisiljeni vrniti v domača semenišča oziroma iskati mesta drugod. Tako sta odšla tudi Burjanek, ki je bil sprejet v semenišče v Litomericah, in Janovski, ki je bil najbrž sprejet v Budweisu (NŠAL, ŠAL V., Semenišče 1891-1899, šk. 230, Laibach am 9. August 1895).

K odhodom iz ljubljanskega bogoslovja pa je na svoj način pripomogel tudi potres, ki je leta 1895 prizadel glavno mesto Kranjske in povzročil ogromno škode. Bogoslovci so bili takrat zaradi razmer v mestu in poškodovane stavbe predčasno poslani domov, kjer so čakali na nadaljnja navodila semeniškega vodstva. Časopisna notica v Slovencu s 17. septembra 1895 je obveščala vse bogoslovce, da so vsa popravila v semenišču dokončana: „Bogoslovne šole se torej brez ovire prično 1. oktobra. Zglaševati se je dan poprej« (S, 17. 9. 1895). Toda ob prihodu so slovenski kolegi opazili, da čeških bogoslovcev ni: »Ko smo prvi dan preštevali naše 
vrste, smo videli, da so zmanjkali vsi češki tovariši razen Hybaška. « Semeniški vodja dr. Ivan (Janez) Kulovic naj za razliko od knezoškofa Missie češkim bogoslovcem ne bi bil preveč naklonjen: "Zato je porabil prvo priliko, da se jih je znebil. Ker je bilo nekaj sob nerabnih, je pisal češkim bogoslovcem, da zanje nima prostora, obenem pa prosil njihove škofe, da jih sprejmejo v svoje semenišče. Na našega Vojteha je pa popolnoma pozabil. Spomnil se je šele takrat, ko se mu je prišel javit. Mislim pa, da jima ni bilo žal. Vojtehu ne, da je ostal pri nas, ravnatelju pa, da mu je pozabil pisati." (Mlakar 1940, 226)

\section{Smrtni primeri}

Če so nekateri odšli zaradi ravnanja vodstva, sprejema v domače semenišče ali izbire druge poti, pa so bili med njimi tudi takšni, ki so v času študija umrli. Že takoj v letu 1887 je umrl študent 1. letnika Jožef Dvǒrak - 31. marca 1887 doma na Češkem zaradi pljučne tuberkuloze (Lungentuberkulose) (NŠAL, ŠAL V., Semenišče 1881-1890, šk. 229, Z. 69, Laibach am 31. März 1887).

Druga smrtna žrtev je bil Vojteh (Adalbert) Havliček. V ljubljansko bogoslovje je vstopil s prvo skupino Čehov in Moravanov v akademskem letu 1885/1886. Pozneje je Havliček, kakor se zdi, dolgo bolehal. Janez Evangelist Krek je o njem leta 1888 zapisal: »Havliček je doma; piše, da mu je bolje; Bog daj, da bi ostal« (Debevec 1923, 62). Zato je bil tudi v letopisu ljubljanske škofije iz leta 1889 zapisan kot valetudinarij (Catalogus cleri 1889, 130-136). Zdelo se je, da mu bo vendarle uspelo doseči življenjski sen - postati duhovnik. Vrnil se je v ljubljansko semenišče in nadaljeval s študijem, a bolezen ni dolgo mirovala in 9. maja 1890, dober mesec dni pred mašniškim posvečenjem, je umrl za tuberkulozo (Lungensucht) (NŠAL, ŠAL V., Semenišče 1881-1890, šk. 229, Z. 60, Laibach am 10. Mai 1890). Tako mu je smrt preprečila uresničitev želje, da bi pristopil k oltarju.

\section{Nove maše}

Tisti, ki so v ljubljanskem semenišču ostali in se poglobili v študij, so takšno željo - mašniško posvečenje - z obilo truda tudi izpolnili. Med Čehi in Moravani jih je bilo največ posvečenih v letu 1889 (štirje); leta 1890 trije; v letih 1888, 1891, 1895 in 1897 pa po en predstavnik. Skupno je torej duhovniški stan doseglo 11 od 23 bogoslovcev s Češke in Moravske, ki so se v obravnavanem času znašli v ljubljanskem bogoslovju.

$\checkmark$ teh letih je bilo o njih kar nekaj govora tudi v časopisju: kje vse in kdaj bodo nove maše potekale. Leta 1888 je mašniško posvečenje prejel Lakmayer, ki je daroval novo mašo 5 . avgusta v Stepanovicah na Češkem (S, 12. 7. 1888). Temu zgledu so pozneje želeli slediti tudi drugi; vsem pa to ni bilo dano in so novo mašo darovali v kateri od ljubljanskih cerkva ali župnij. Leta 1890 je tako novo mašo 29. julija že ob 6. uri zjutraj daroval novomašnik Edvard Kosobud; isto poletje je Vaclav 
Vondrašek je 3. avgusta maševal doma v Purkarcu na Češkem (S, 8. 7. 1890). Že leto prej se je s takšnim vprašanjem - kje darovati prvo mašno daritev - srečal tudi Franc Hiersche. Časopis Slovenec je 8. avgusta 1889 poročal, da si je izbral Horjul in še dodal, da se je s krajem in ljudmi, posebej pa z gospodom župnikom, seznanil že kot bogoslovec. Takrat je večkrat prihajal pomagat župniku »pri raznih cerkvenih opravilih. Priljubil se je g. župniku in ljudem, zatorej so ga naprosili g. župnik in farani, da bi v Horjulu imel svojo novo mašo. « Tja so seveda prišli njegovi domači »iz daljne češke dežele«, pridigal pa mu je semeniški direktor in protonotar dr. Kulavic sam (S, 8. 8. 1889). Podobno so se znašli tudi drugi, ki niso odpotovali domov in so tako prve daritve opravljali po župnijah ljubljanske škofije. Med temi je bil tudi Viljem Paulus, ki je pel novo mašo 28. julija 1895 v ljubljanski trnovski cerkvi (ZD, 12. 7. 1895, 228).

\section{3. Češki duhovniki v šematizmu za I. 1898 in v Letopisu 2000}

Po mašniškem posvečenju in novih mašah so mladi duhovniki čakali na prve namestitvene dekrete, s katerimi so bili poslani v pastoralo na različna mesta $v$ ljubljanski škofiji. Škofijski letopis iz leta 1898 (Catalogus cleri 1898) podaja naslednjo sliko, kje vse so ti duhovniki delovali: Ferdinand Čekal je bil takrat vpisan v šematizem kot dušni pastir in župnik v Studencu; ob tem je bil za tisti okraj še šolski inšpektor in šolski svetovalec (Catalogus cleri 1898, 73).

Venčeslav (Wenceslaus) Filler, ki je mašniško posvečenje prejel 23. julija 1891, je v letopisu predstavljen kot kaplan v Šentrupertu v dekaniji Trebnje (Catalogus cleri 1898, 130).

V ljubljanski dekaniji je kot župnik v Sori (Zayer) deloval gospod Frančišek Sal. Hiersche (Catalogus cleri 1898, 36; 202).

Edvard Kosobud je po mašniškem posvečenju 19. julija 1890 ostal v ljubljanski škofiji. Šematizem ga takrat navaja kot kaplana v Cerkljah, v kranjski dekaniji (Catalogus cleri 1898, 61; 205). Frančišek Lakmayer (Lakmaier) je bil župnik v Grahovem, v cerkniški dekaniji $(40 ; 206)$. Jožef Mensinger je bil kaplan na Mirni (129; 207), Viljem (Giulielmus) Paulus pa je bil zapisan v šematizem kot kaplan v Dolah, kjer je župnikoval Ignacij Šalehar (1898, 75; 209).

V šematizmu je v imenskem kazalu mogoče zaslediti tudi Bernarda Polaka z Moravske - Schönstein. Rojen je bil 12. junija 1853. V mašnika je bil posvečen 28. julija 1878 in bil leta 1898 nastavljen za rektorja križniške cerkve B. M. V. Takrat je bil subprior ljubljanskega konventa križniškega reda (Catalogus cleri 1898, 28; 210).

Janez Soukup je v letopisu za leto 1898 omenjen kot župnik pri cerkvi svete Magdalene v župniji Gora v idrijskem dekanatu (Catalogus cleri 1898, 50; 212).

Viljem (Guilielmus) Vesel, ki je bil posvečen 17. avgusta 1867, je bil član križniškega reda. Tako ga leta 1898 najdemo v ljubljanski škofiji, kjer je kot upokojeni župnik vikar in šolski inšpektor živel v Črnomlju. Zaznamek križa pri njegovem zapisu v šematizmu nakazuje, da je očitno tega leta tudi umrl (Catalogus cleri 1898; 
118; 214). Venčeslav Vondrašek, doma iz Purkarca na Češkem, je tudi ostal v ljubljanski škofiji. Študij je dokončal v Ljubljani in bil posvečen 19. julija 1890. Osem let pozneje je opravljal službo kaplana v Šentjerneju v leskovškem dekanatu (69; 214). Alojzij Železný, zadnji predstavnik Čehov in Moravanov v tem letopisu, je bil posvečen v mašnika 17 . avgusta 1889 , v šematizmu iz leta 1898 pa je predstavljen kot kaplan v župniji Št. Jurij pri Kranju $(, 62 ; 215)$. Poleg njih je v letopisu mogoče zaslediti še nekatere druge redovnike in redovnice, ki so prihajali iz čeških dežel ali Moravske.

\section{Letopis $\mathbf{2 0 0 0}$}

Podobno bi lahko na podlagi letopisov in službenih tabel natančno spremljali službena mesta vsakega od omenjenih mašnikov iz dežel sv. Vaclava, ki so ostali na naših tleh še po razpadu habsburške monarhije, kar izpričuje tudi Letopis Cerkve na Slovenskem iz leta 2000. Po podatkih iz tega letopisa, natančneje iz tam objavljenega nekrologa za ljubljansko nadškofijo, je v ljubljanski škofiji od leta 1901 naprej umrlo 10 duhovnikov s koreninami na Češkem ali Moravskem. Skromen pregled predstavlja naslednje, večinoma že znane in omenjene osebe: že leta 1910 je umrl Viljem Paulus, župni upravitelj župnije Izlake v pokoju; leta 1918 je umrl Josef Mensinger, ki je bil deset let prej beneficiat na Razdrtem; leta 1924 je umrl Janez Soukup, župnik pri Stari Oselici; leta 1927 je v Ljubljani kot kanonik umrl dr. Ferdinand Čekal; istega leta je preminil tudi mladi duhovnik Michael Herman, kaplan v Stari Cerkvi pri Kočevju. V letu 1937 je na Jezerskem umrl tamkajšnji župnik Janez Drunecký; v letu 1947 je umrl prof. glasbe v Zavodu svetega Stanislava Vojteh Hybašek (Letopis 2000, 413-450); leta 1946 Franc Serafin Lakmayer (tudi Lakmaier), upokojeni preddvorski župnik, ki je s svojo knjigo Umno čebelarstvo pustil pomembno sled v razvoju čebelarstva (Zaletel 1988, 10-11); leta 1954 je umrl Frančišek Hiersche in v letu 1960 še zadnji živeči predstavnik generacije Čehov, ki so se šolali v Ljubljani, Alojzij Železný (Letopis 2000, 413-450).

Na tem seznamu najdemo tudi dve neznani, $z$ ljubljanskim semeniščem $v$ resnici nepovezani osebi: Drunecký in Herman. Drunecký se je šolal v celovškem bogoslovju in pozneje dolgo časa deloval v tamkajšnji škofiji. Leta 1920 je kot begunec prišel na Bled, od tam pa je odšel najprej v Begunje, kjer je »dve leti brezplačno opravljal kaplansko službo. Leta 1923 je prišel na Jezersko, kjer je bil najprej župni upravitelj, nato do leta 1931 župnik. « Umrl je 23. junija 1937 (S, 24. 6. 1937, 3).

Mladi in prezgodaj umrli kaplan Michael Herman je bil rojen leta 1900 na Češkem in je študiral bogoslovje v Litomericah, kjer je 11. novembra 1923 prejel mašniško posvečenje. Po posvečenju je prišel v ljubljansko škofijo, kjer je bil štiri leta kaplan v Stari Cerkvi, kakor je ob njegovi prezgodnji smrti leta 1927 poročal Slovenec (23. 11. 1927, 4). Čeprav ne Drunecký ne Herman nista izhajala iz kroga tistih, ki so ob koncu 19. stoletja študirali v Ljubljani, se vendarle zdi primerno vsaj na ta način spomniti tudi na njun prispevek in delovanje $v$ dušni blagor naših prednikov. 


\section{Namesto sklepa - pobuda}

Pričujoči prispevek predstavlja le skromen oris, ki poskuša prikazati razgiban čas v letih 1885-1896, ko so v ljubljanskem semenišču študirali tudi duhovniški kandidati z Moravske in Češke. Od triindvajsetih kandidatov, ki so začeli svoj teološki študij v Ljubljani, jih je bilo le enajst takšnih, ki so študij dejansko dokončali, v Ljubljani prejeli mašniško posvečenje in bili vpeti v pastoralno delo v ljubljanski škofiji. Kljub manjšemu številu duhovnikov čeških in moravskih korenin (v primerjavi denimo z Istro in Primorjem) pa je bil njihov prispevek na polju pastorale in tudi na drugih področjih opazen. Peščica jih je v slovenskem prostoru pustila celo trajne sledi - bodisi na področju glasbe bodisi v čebelarstvu. Vsak od njih bi si zaslužil posebno študijo in predstavitev velikokrat zelo razgibanih življenjskih poti. Naš prispevek je tako le kratek oris, ki podaja nekaj informacij o vpletenosti čeških duhovnikov v delo med Slovenci v obdobju pred veliko vojno in prevratom ter odpira več vprašanj; to pa pomeni, da na svoj način predstavlja tudi pobudo za nadaljnja raziskovanja. Na podoben način bi tako v prihodnje veljalo raziskati in predstaviti še študij čeških duhovnikov v celovškem in lavantinskem semenišču ter njihovo delovanje v teh škofijah; podobno velja tudi za delovanje čeških duhovnikov v sekavski škofiji in še bolj podrobno za že nekoliko obdelano tvarino v delih že omenjenega zgodovinarja Boruta Klabjana o duhovnikih v Istri in na Goriškem. Na ta način bi postopoma uspeli ustvariti celovit pregled o vpetosti čeških in moravskih duhovnikov v pastoralno in družbeno delovanje v deželah Notranje Avstrije - česar do sedaj v takšnem obsegu v slovenskem zgodovinopisju še nimamo.

\section{Krajšave}

NŠAL - Nadškofijski arhiv Ljubljana.

S - Slovenec. 1873-1945 Političen list za slovenski narod. Ljubljana: Ljudska tiskarna.

SN - Slovenski narod. 1873-1945. Političen list za slovenski narod. Ljubljana: Ljudska tiskarna.

ŠAL - Škofijski arhiv Ljubljana.

ZD - Zgodnja Danica. 1849-1902. Katoliški cerkveni list. Ljubljana: Janez Krizostom Pogačar.

\section{Reference}

Arhivski viri

NŠAL 32, Bogoslovno semenišče v Ljubljani, šk. 75, Katalogi slušateljev teologije 1885-1897.

NŠAL, ŠAL V., Semenišče 1881-1890, šk. 229, An das Hochwürdigste Fürstbischöfliche Ordinariat, 9. 9. 1885.

-, Semenišče 1881-1890, šk. 229, An die hochw.
Direktion des fb. Klerikalseminar in Laibach, 3. 10. 1885.

\footnotetext{
-, Semenišče 1881-1890, šk. 229, Höchwürdigtes fürstbischöfliches Ordinariat, Laibach am 25. Sept. 1885.

-, Semenišče 1881-1890, šk. 229, Z. 69, Laibach am 31. März 1887.
} 
-, Semenišče 1881-1890, šk. 229, Z. 204, Laibach 1. August 1887.

-, Semenišče 1881-1890, šk. 229, Z. 166, Laibach am 21. August 1889.

-, Semenišče 1881-1890, šk. 229, Z. 60, Laibach am 10. Mai 1890.

-, Semenišče 1891-1899, šk. 230, Laibach am 9. August 1895.

-, Semenišče 1891-1899, šk. 230, Reverendissime.

-, Semenišče 1891-1899, šk. 230, No. 7663.

\section{Tiskani viri}

Letopis Cerkve na Slovenskem 2000: stanje 1. januar 2000. 2000. Ljubljana: Nadškofijski ordinariat.

Almanach des katholischen Klerus Oesterreichs und Ungarns. 1912. Dunaj: Selbstverlage.

\section{Časopisi}

Slovenec. 11. 8. 1887, s. p. Bratje Čehi v beli Ljubljani.

-. 29. 8. 1885, s. p. $V$ bogoslovje.

-. 17. 9. 1895, s. p. Bogoslovne šole.

-. 20. 8. 1886, s. p. V duhovska semenišča.

-. 23. 11. 1927, 4. Umrl.

-. 24. 6. 1937, 3. Župnik J. Drunecky.

-. 8. 7. 1890, s. p. Čč. gg. novomašniki ljubljanske škofje.

-. 8. 8. 1889, s. p. Iz Horjula.

-.9. 8. 1887, s. p. Prihod bratov Čehov v belo Ljubljano.

Slovenski narod. 9. 10. 1885, s. p. V ljubljansko semenišče.

Zgodnja danica. 12. 7. 1895, 228. Novomašniki in nove maše.

\section{Druge reference}

Ambrožič, Matjaž. 2010. Prvih tisoč let krščanstva na Slovenskem. Priročniki Teološke fakultete 20. Ljubljana: Teološka fakulteta.

- - - 2010a. Spomini in semeniška kronika 19411944 Ignacija Nadraha. Ljubljana: Arhivsko društvo Slovenije.

- - . 2010b. Prva Teološka fakulteta in kn. šk. Bogoslovno učilišče v Ljubljani. V: Teološki študij na Slovenskem: vloga teoloških izobraževalnih ustanov v slovenski zgodovini pri oblikovanju visokošolskega izobraževalnega sistema, 351-450. AES 32. Ur. Matjaž Ambrožič. Ljubljana: Inštitut za zgodovino Cerkve pri Teološki fakulteti.
Baraga, France, ur. 2003. Letopis ljubljanskega kolegija Družbe Jezusove (1596-1691). Ljubljana: Družina: Provincialat Družbe Jezusove.

Catalogus cleri dioecesis Labacensis. 1880-1898. Ljubljana: s.n.

Dolenec, Ivan, ur. 1923. V: Janez Ev. Krek. Izbrani spisi. Zv. 1, Mlada leta (1865-1892). Ljubljana: Društvo dr. Janez Ev. Krek v Ljubljani.

Dolinar, France Martin. 1982. Letopisi ljubljanske (nad)škofije kot zgodovinski vir. Zgodovinski časopis 36, št. 3:231-241.

Klabjan, Borut. 2007. Češkoslovaška na Jadranu. Koper: Annales.

Mlakar, Janko. 1940. Spomini. Ljubljana: Jugoslovanska tiskarna.

Pokorn, Frančišek. 1908. Šematizem duhovnikov in duhovnij v ljubljanski nadškofiji I. 1788. Ljubljana: Knezo-škofijski ordinariat ljubljanski.

Valenčič, Vlado. 1974. Etnična struktura ljubljanskega prebivalstva po ljudskem štetju 1880. Zgodovinski časopis 23, št. 3-4:287-319.

Vinkler, Jonatan. 2006. Posnemovalci, zavezniki in tekmeci. Koper: Annales.

Zaletel, Pavel. 1988. Utrl je pot naprednemu slovenskemu čebelarstvu: Franc Lakmayer njegovo življenje in delo. Slovenski čebelar 90, št. 1:9-11. 